\title{
35. ENGINEERING AND OTHER PHYSICAL PROPERTY DATA, LEg 43
}

\author{
K. R. Demars, University of Delaware, Newark, Delaware \\ and \\ V. A. Nacci and W. E. Kelly, University of Rhode Island, Kingston, Rhode Island
}

\section{INTRODUCTION}

Representative core specimens from each drill site of Leg 43 were sampled for physical property testing. Tests were typically performed onboard ship with equipment that was installed for speed, convenience, and due consideration for precision. In addition, three core specimens were taken at Site 387 for more detailed strength and compression analyses at a geo-technical laboratory.

Discrete shipboard measurements of vane shear strength, water content, wet bulk density, and sonic velocity were made. Continuous nuclear bulk density measurements were obtained for most core samples with GRAPE (gamma ray attenuation porosity evaluator). These data are presented in tabular form in the site reports (chapters 2-7) and Appendix V. The techniques used to obtain these results have been described by other participants in DSDP (Bennett and Keller, 1973; Lee, 1973; Boyce, 1974; Rocker, 1974) and additional discussion is here not necessary. Equipment precisions are well within tolerable limits and ship movement was small and had little influence on the measurements used for water content and density. Unfortunately, the measured properties may vary substantially from their in situ values because of poor sample quality. This effect will be discussed further in subsequent sections.

Three core samples from Site 387 were taken to acquire more detailed engineering data and some additional information on sample disturbance. Both triaxial compression and one-dimensional compression tests were performed on the core samples in addition to the standard index properties. The available laboratory equipment imposed a sample depth limit of about 100 to 150 meters below the sea floor; therefore, samples were only obtained from the first two cores at Site 387.

\section{GENERAL SAMPLE DESCRIPTION}

Detailed geological descriptions of the sediment profiles for each site are provided in the Site Reports. Additional general descriptions are inserted here with some comments on factors which influence physical property values.

The sediments tested at Sites 382, 385, 386, and 387 are predominantly clays with some silt. Small quantities (less than 10 per cent by weight) of sand-sized particles including foraminifers and radiolarians and silt-sized nannofossils are frequently present, but they are not of sufficient abundance to significantly influ- ence physical property results or affect engineering behavior. Occasional layers with high contents of calcareous and siliceous particles were found at most sites. Also, fine sand layers of quartz are observed as part of the turbidite sequences found at Site 382 and other sites. In general, sand layers are relatively thin and constitute only a small portion of each core. The sand layers may not be representative of in situ layering because of the coring method. Interbedded layers of limestone, chert, and breccia were periodically observed.

At Site 384 , the sediments are predominantly nannofossil oozes and chalks with a substantial quantity of silt and clay. Carbonate content varies from about 40 to 75 per cent by weight over the length of core, with 10 to 20 per cent foraminifers and unspecified or detrital carbonate. The nannofossil particles are typically 2 to $7 \mu \mathrm{m}$ in diameter or silt-sized. They are of irregular shape and have been observed to exhibit granular behavior (Demars, 1975). Also, the nannofossil particles have interstices which are capable of storing water; consequently, they have water contents based on dry weight which are 30 to 50 per cent greater than would be estimated by their grain size distribution.

Turbidities were encountered at Site 383 to a subbottom depth of 120 meters at which point the hole was terminated because of unstable side-wall conditions. One core was obtained in the interval from 54 to 64 meters below the sea floor. It contains a perfectly graded sequence of fine to very coarse sand and is obviously a result of sample disturbance. No physical property tests were performed on this core sample.

Many of the cored sequences contain thin layers of Eocene chert and strongly cemented sediment at subbottom depths greater than 150 meters. The extent of cementation is not certainly known because of the low core recovery that is typically less than 20 per cent in cemented materials. Both carbonate and silica cements were observed, but it is possible that other cementing agents, such as oxides or organic material, are also present. It is also particularly difficult to distinguish the transition from some uncemented to cemented layers, as between ooze and chalk at Site 384 . Cemented layers were identified by their resistance to deformation by the edge of a fingernail or metal spatula, suggesting a stronger and denser structure than adjacent compacted sediment layers. It is probably these cemented sediments, cherts, and turbidities which show up as reflectors during seismic profiling. The acoustic and other physical properties will be discussed subsequently. 


\section{DISTURBANCE AND SAMPLING PROCEDURES}

Sample disturbance is the single most important factor influencing the quality of engineering and physical property data. As a result, it is necessary to use care and judgment in the selection of specimens most representative of in situ conditions. The rotary drilling technique used in this program tends to homogenize the sediment samples from the churning action and excess back-pressures of drilling muds and cuttings, but frequently blocks or chunks of "undisturbed" or only slightly disturbed specimens may be observed among highly remolded drilling breccia or muds.

For shallow samples $(<200 \mathrm{~m})$ drilling breccia or disturbed mud may be observed over an entire core with the least visual disturbance occurring at the lower end of each core. The best specimens are, therefore, from the core catcher or bottom-most section of core. Cores deeper than 200 meters generally contain chunks of intact specimens in all parts of a core that are suitable for shipboard properties testing. The task is to select the least disturbed or undisturbed chunks or segments for properties testing. It is a particularly difficult task for homogenized soft sediment cores which are most disturbed yet often visibly devoid of disturbance signs.

From a physical properties viewpoint, disturbance of two different types is possible during the sample cutting process: (a) remolding without a water content change, and (b) remolding with the addition of water. The former will have less effect on shipboard measurements of in situ water content, bulk density values, and acoustic velocity than the latter. However, vane shear strengths are sensitive to both remolding and water content changes, and strength reductions of 75 per cent or more from in situ values may be expected.

Particle size gradation, accessibility of water, and corer geometry are among the factors that influence disturbance. Since the DSDP samples are of poor geometry for geotechnical specimens according to Hvorslev (1949), highly disturbed cores are expected. In general, granular soils are more permeable and more susceptible to density change in a short time. As expected, the greatest variations in water content occur in calcareous (granular) sediments. This conclusion is deduced in part from the data shown in Figure 1, which indicate a decrease in strength from bottom to top in each core. The data suggest that the nanno ooze is remolded to a greater degree as it intrudes further into the core liner. Water content data (see Site Reports) show the reverse trend, with water contents increasing by 2 to 12 per cent from bottom to top in a core. In general, water content change during the core cutting process is only significant in high carbonate or granular sediments. No significant variations in water content are observed over the length of a core containing homogeneous clay sediments, suggesting that water is not added to these sediments during the core cutting process.

During sample retrieval (about one and a half to two hours) and sample storage prior to processing (up

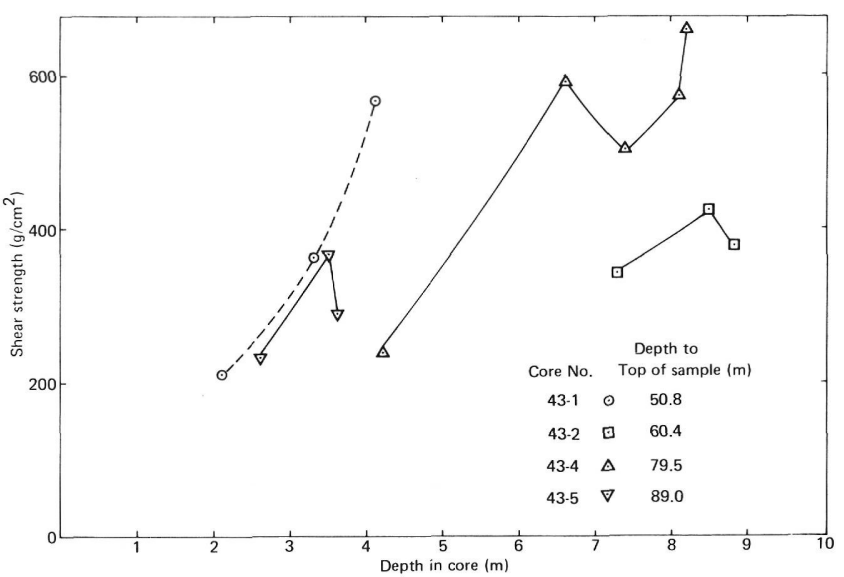

Figure 1. Variation in undrained shear strength with depth in core for Site 384 nannofossil oozes.

to ten hours), the samples are expected to swell in volume and absorb water. This process is possible because of the poor sample fit within the liner. The presence of a water void or drill mud between sample and liner implies that the in situ effective stress has, for practical purposes, been reduced to zero and that unconfined expansion will occur during the core retrieval. This type of disturbance will be referred to as drained unloading, and it is discussed later in this paper. Drained unloading can have a significant effect on the bulk physical properties and strength behavior of sediments.

Additional disturbance arises in the core splitting process and the requirement that specimens be tested at room temperature of about $23^{\circ} \mathrm{C}$ rather than in situ temperatures of about $2{ }^{\circ} \mathrm{C}$.

Core splitting by either a wire saw or powered abrasive saw appears to have little effect on remolding specimens of the size needed for shipboard tests. However, on the basis of visual observations, temperature effects appear significant. These observations include the cracking of deeply buried $(>300 \mathrm{~m})$, compact specimens and the rapid absorption of water on the surface of split cores. These changes occur over a span of a minute or less and might be due to peripheral warming and expansion of the sample which places the central cold portion in tension until a crack initiates. Because of the dense particle arrangement of deep samples, temperature-induced volume changes cause specimens to expand and absorb water in the process. Thus, the water contents are increased and densities decreased. Water is available from voids, drilling mud, or breccia that exist between the specimen and core liner or by water added in the core-splitting and cleaning process. This temperature expansion and subsequent change in density and water content is in addition to the reduction of density from hydrostatic and in situ stress unloading.

Much of the work done on the effects of temperature on geotechnical properties of terrestrial soils has been summarized by Mitchell (1976). Little, if any, research has been directed specifically at marine sediments. Under conditions of constant stress an increase in temper- 
ature can be expected to cause a decrease in volume (a decrease in water content). However, high-swelling soils have been observed to increase in volume at constant pressure with an increase in temperature. Since the cores being analyzed are relatively high in montmorillonite (see Table 1), these observations are not in conflict with results for terrestrial soils.

There is also the possibility of thermally induced flow (Yong and Warkentin, 1975). Although thermally induced flow is not considered important at high saturations, there is too little data to dismiss it in the present instance. At the high effective stresses being considered, relatively minor changes in water content, because of the exponential dependence of strength on water content, can cause relatively large changes in strength. It is of interest to note that Sherif and Burrows (1969) found that for a campacted kaolinite clay, the effect of temperature changes in unconfined shear strength could be accounted for by an experimentally determined moisture content correction.

Sampling for land-based engineering and physical properties testing was performed with most of this information at hand. Three short $(15$ to $25 \mathrm{~cm})$ specimens were selected from the first two cores at Site 387. Two samples were taken from the bottom of the last two sections, of Core 1 corresponding to sub-bottom depths of 39.0 meters and 40.4 meters and one sample was taken from the bottom of Core 2, or at 105.8 meters. The samples were cut immediately upon arrival of the core on deck to prevent warming and prior to splitting, since cylindrical specimens are needed for strength and compression testing. All specimens were capped immediately, wrapped in moist paper towels and polyethylene sheet, and refrigerated until arrival in port. The samples were shock-mounted in styrofoam beads for return to laboratory refrigerated storage. An unknown degree of warming occurred from ship to laboratory. The objectives were to sample the least-disturbed portions of the cores and minimize additional disturbance from shock and temperature.

\section{SHIPBOARD RESULTS AND ANALYSIS}

All shipboard data are presented in graphical and tabular form in the site reports. Additionally, shipboard data for Site 387 are reconsidered here since both laboratory and shipboard samples were taken at this site. The general effects of compaction or lithological changes on test results are discussed as well as the effects of factors such as disturbance and cementation.

\section{Porosity and Bulk Density}

Seven lithologic units were encountered above basement at Site 387. These units are summarized in Figure 2 , where the shipboard porosity and bulk density data are shown graphically. No corrections have been made for unloading or coring and thermal disturbance to reconstruct in situ values. The general trend with subbottom depth is a decrease in porosity and an increase in wet bulk density. A trend line has been included for sediments to show the effects of compaction or consolidation from overburden. If each lithologic unit is considered separately, similar trends are observed for uncemented units, but the data are disconnected at the lithologic boundaries. These data show the importance of grain size and mineralogical composition of each unit. Also, the data show the significance of other sedimentary processes such as the cementation by silica in Unit 3 , by carbonate in Unit 7 , and possible organic cementation in the black shales and chalks of Units 4 , 5 , and 6 (about 460 to $490 \mathrm{~m}$ sub-bottom). Most test results which are displaced to the left of the porosity trend line and to the right of the bulk density trend line fall into the cemented category based upon field observations. A small amount of scatter about the trend line is attributed to sampling disturbance as evidenced for Site 384 (Figure 1). Most scatter, however, is attributed to compositional variations. For example, samples from Units 2 and 3 contain a large quantity of siliceous materials such as radiolarians and sponge spicules, and they exhibit slightly lower densities and

TABLE 1

Sample Data

\begin{tabular}{|c|c|c|c|c|c|c|c|c|c|}
\hline $\begin{array}{l}\text { Sample } \\
\text { (Interval } \\
\text { in } \mathrm{cm} \text { ) }\end{array}$ & $\begin{array}{l}\text { Sub- } \\
\text { bottom } \\
\text { Depth } \\
\text { (m) }\end{array}$ & $\begin{array}{c}\text { Adjusted } \\
\text { Dry } \\
\text { Water } \\
\text { Content } \\
(\%)\end{array}$ & $\begin{array}{l}\text { Liquid } \\
\text { Limit } \\
(\%)\end{array}$ & $\begin{array}{c}\text { Plastic } \\
\text { Limit } \\
(\%)\end{array}$ & $\begin{array}{l}\text { Plas- } \\
\text { tic- } \\
\text { ity } \\
\text { Limit } \\
(\%)\end{array}$ & $\begin{array}{l}\text { Total } \\
\mathrm{CaCO}_{3} \\
(\%)\end{array}$ & $\begin{array}{l}\text { Sand/ } \\
\text { Silt/ } \\
\text { Clay } \\
(\%)\end{array}$ & $\begin{array}{l}\text { Bulk } \\
\text { Unit } \\
\text { Weight } \\
\text { (g/cc) }\end{array}$ & $\begin{array}{c}\text { Soil } \\
\text { Type }\end{array}$ \\
\hline $1-5,15$ & 39.0 & 105.0 & 118.0 & 46.0 & 72.0 & $<3 \%$ & $0 / 4 / 96$ & 1.47 & $\mathrm{CH}$ \\
\hline $1-6,25$ & 40.4 & 84.0 & 122.0 & 44.0 & 78.0 & $<3 \%$ & - & 1.52 & $\mathrm{CH}$ \\
\hline $2-5,25$ & 105.8 & 96.5 & 181.0 & 59.0 & 122.0 & 0 & - & 1.47 & $\mathrm{CH}$ \\
\hline
\end{tabular}

Note: Sample $1-5,15 \mathrm{~cm}$ : Very soft plastic pale brown clay - some mottling with distorted appearance. Clay minerals $(<2 \mu \mathrm{m})$ include: $12 \%$ Kaolinite, $42 \%$ Illite, $7 \%$ Chlorite, and $39 \%$ Montmorillonite.

Sample 1-6, $25 \mathrm{~cm}$ : Soft plastic pale brown clay - no visible signs of disturbance.

Sample 2-5, $25 \mathrm{~cm}$ : Medium to stiff plastic pale olive clay - crumbles when trimmed - several hairline cracks through sample. Clay minerals $(<2 \mu \mathrm{m})$ include: $10 \%$ kaolinite, $16 \%$ illite, $3 \%$ chlorite, and $71 \%$ montmorillonite. Radiographs show all samples to be homogeneous with several small $(2-4 \mathrm{~mm}$ diameter), dense particles in Sample 2-5, $25 \mathrm{~cm}$. Mineralogy data from Koch and Rothe (this volume). 

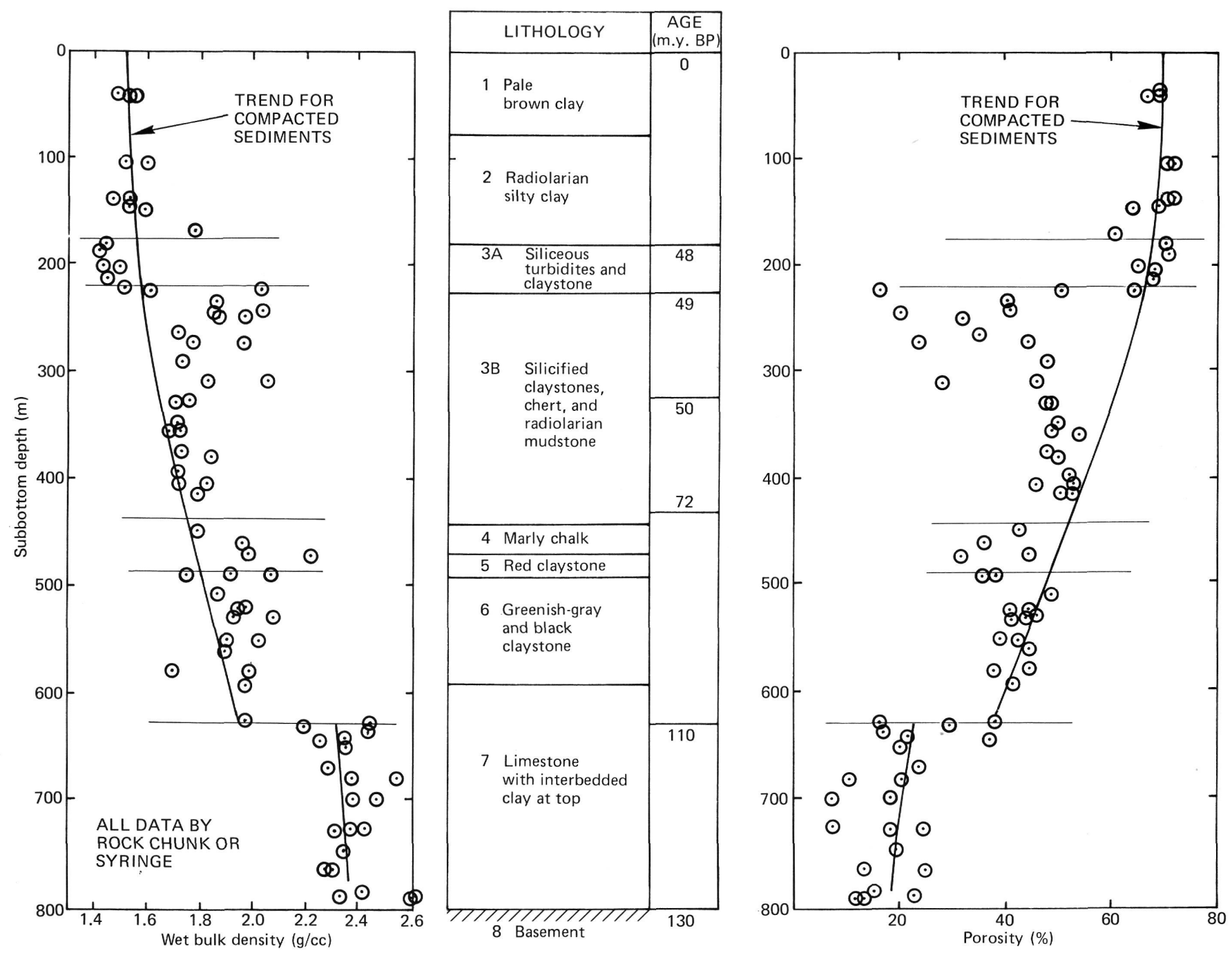

Figure 2. Lithology, wet bulk density, and porosity data for Site 387.

higher porosities than adjacent units. These trends for siliceous sediment agree with the test results of Lee (1973). In general, mineralogical and grain size variations and cementation have a greater influence on bulk density and porosity than does disturbance.

\section{Shear Strength}

Of all physical properties, undrained shear strength is perhaps the most sensitive index of sample disturbance. Disturbance can result from sampling, core handling, temperature changes, addition of water, degasification (not a problem on Leg 43), and testing technique as previously discussed. A thorough remolding of a sample will reduce undrained shear strengths to onethird or one-fourth the in situ values because most marine sediments have sensitivities of 3 to 4 (Noorany and Gizinski, 1970; Demars, 1975). Sensitivity is defined as the ratio of undisturbed strength to remolded strength. Also, a small change in water content will have a significantly greater effect on strength than upon porosity or bulk density values as discussed in the previous section. As a result, it is desirable to perform laboratory strength or compression tests so that the state of effective stress can be controlled or monitored during testing.

Overburden pressure or confining pressure has the most significant influence upon the shear strength of normally loaded sediments. The ratio

$$
c / p=0.11+0.0037 P I
$$

for undrained strength $(c)$ to in situ overburden pressure $(p)$ has been proposed by Skempton (1954), for normally loaded clays, and is dependent on plasticity index $(P I)$. Kenney (1967) suggests $c / p=0.20$, although this is probably a lower limit of $c / p$ values. Maximum $c / p$ ratios of 0.3 to 0.4 are common for normally loaded clays, and minimum ratios of 0.1 or less have been estimated for underconsolidated delta-front marine sediments. All of these $c / p$ values may vary significantly depending on the techniques used to determine $c$ and $p$.

Vane strength data for Site 387 are presented in Figure 3 to show the influence of sample disturbance 


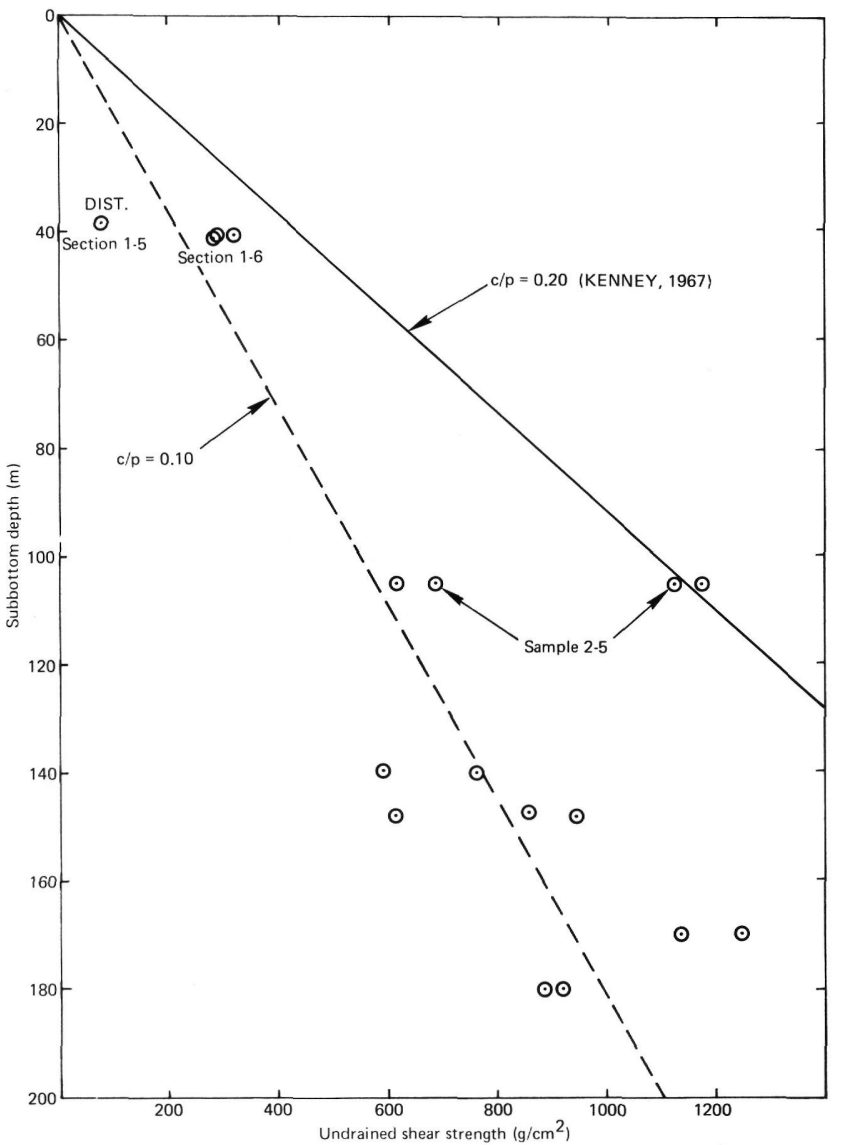

Figure 3. Vane shear strength data for Site 387 clays.

on strength. For comparison purposes, $c / p$ ratios of 0.1 and 0.2 are shown with effective pressures $(p)$ computed with a buoyant unit weight of $0.50 \mathrm{~g} / \mathrm{cc}$ that exists from shipboard density tests. All data fall below the $c / p=0.20$ relationship and agree favorably with $c / p=0.10$. Laboratory triaxial test results, which are discussed subsequently, suggest that actual $c / p$ ratios may be 0.30 to 0.35 . Thus, the best DSDP specimens available for shipboard strength analyses are highly disturbed, although thorough remolding is unlikely based on the detailed stratigraphic features of the split core samples.

There has been an attempt to correct for disturbance in DSDP samples (Lee, 1973) by measuring residual negative pore water pressures for comparison with expected values. Although this technique has some merit, several assumptions are required to correct the strength values, and the accuracy is limited to \pm 50 per cent of in situ values. It is unknown if the effects of temperature changes, degasification, and water content changes can be corrected. Consequently, laboratory strength and compression testing or in situ investigations are recommended for determination of representative in situ properties. Even those sophisticated methods require care in the interpretation of results, and the aged, cemented, and thermally altered specimens require additional study.

\section{Acoustic Velocity}

Acoustic velocities were obtained to assist in the interpretation of seismic reflection data for stratigraphic analyses. Sedimentary units with contrasting impedances (product of acoustic velocity times bulk density) reflect sound from the interface and provide an acoustic image of the physical stratigraphy. Acoustic velocity and impedance data for Site 387 are shown in Figure 4. At the sediment-water interface, impedance contrasts of about 40 per cent appear to provide excellent reflections for the frequency range considered (40 to 640 $\mathrm{Hz}$ ). Smaller impedance contrasts within a sediment profile also probably provide good reflective qualities. Unfortunately, there appear to be little available data on the magnitude of impedance contrasts needed for good seismic reflection profiles, and more work is needed on this topic for improved geological interpretation of seismic data.

Multiple sedimentary units, each with different acoustic impedances, provide very complex reflection patterns as is evident from a simple acoustic ray diagram. Sound propagation is also influenced by group spreading of each pulse which further complicates seismic profile data. As a result, many acoustic laminations occur for each seismic profile. Only a select few of these laminae appear to correlate with physical stratigraphic features. It is, therefore, necessary to couple seismic reflection data with bore hole and laboratory results for a detailed analysis of the stratigraphy in a region.

The data shown in Figure 4 and the seismic profile show several reflective horizons as discussed in the Site Report. The seismic interpretation for Site 387 lists six reflective horizons: $A$ at 170 meters, $A$ at 223 meters,

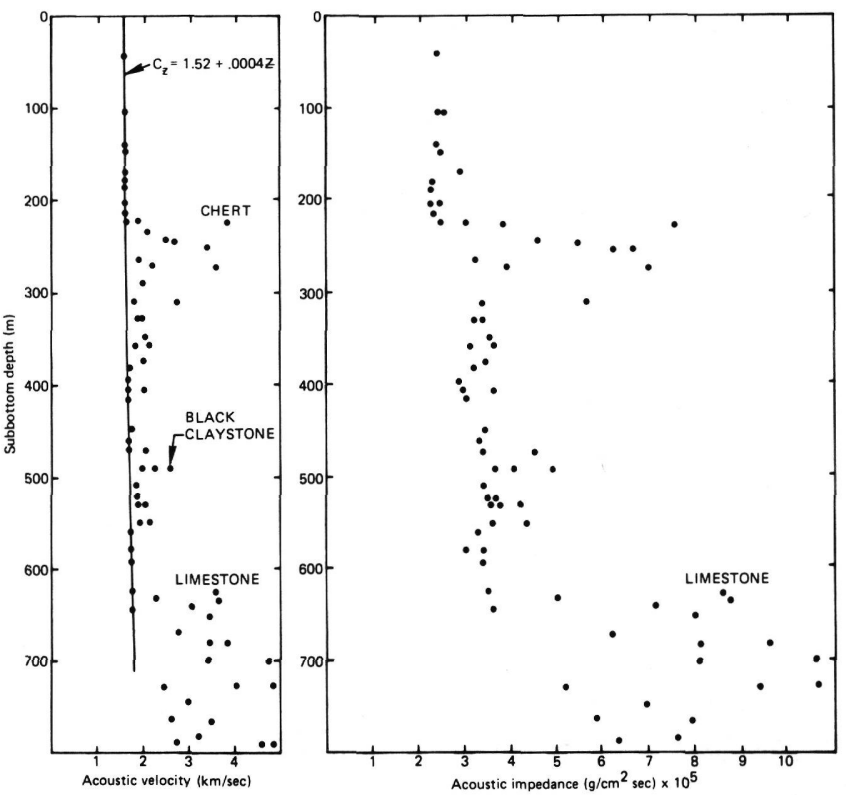

Figure 4. Acoustic velocity and impedance data for Site 387. 
unspecified at 360 meters, $A^{*}$ at 470 meters, $\beta$ at 600 meters, and basement at 792 meters. Seismic profiling results show many more acoustic laminae. Each lamination is not necessarily the result of a lithological change or impedance contrast. Impedance contrasts for the profile are as small as 20 per cent for horizon $\bar{A}$ at 170 meters to over 300 per cent for horizon $A$ at 223 meters. The six major reflective horizons occur at the interface of compacted sediments of low impedance and cemented sediments of high impedance. For cemented sediments, the acoustic velocity, bulk density and, thus, acoustic impedance appear to increase as the cementation strengths of the sediment increases.

Little variation in the acoustic velocity of compacted sediments is observed or expected (Hamilton, 1974). In general, the acoustic velocity is influenced slightly by effective pressure (Laughton, 1957), which increases the density of the sediment. For most sites, the acoustic velocity may be expressed in terms of effective pressure or more simply a velocity gradient with subbottom depth by

$$
V z=1.52+0.0004 Z(\mathrm{~km} / \mathrm{sec})
$$

where the subbottom depth $Z$ is in meters, and the velocity gradient is $0.0004 \mathrm{~km} / \mathrm{sec} / \mathrm{m}$ or $0.4 \mathrm{sec}^{-1}$. This velocity variation with subbottom depth is not very sensitive to effective stress changes, and samples from great depths have velocities which vary only slightly from the velocity of saltwater. An observed gradient of $0.4 \mathrm{sec}^{-1}$ was noted for all uncemented clays tested at room temperature and pressure. This gradient is slightly lower than the field gradient of $0.5 \mathrm{sec}^{-1}$ or greater obtained by Hamilton. The low gradients reported here are undoubtedly influenced by sample disturbance including drained unloading as discussed in the next section. The work of Laughton (1957) shows that drained unloading can reduce acoustic velocity and also velocity gradient.

For calcareous sediments as observed at Site 384, it is believed by Schlanger et al. (1973) that oozes convert to chalk below about 200 meters of overburden and to limestone at about 600 meters. Diagenetic alteration of the calcareous particles results in cementation during this burial process. It is most probable that cementation is gradual and increases with subbottom depth as opposed to being confined to distinct layers as observed at other sites where cementing agents are present. The cementation process with depth should be apparent in the acoustic profile for Site 384 since cementation influences acoustic velocity. The shipboard velocity data for Site 384 are shown in Figure 5 where the aforementioned velocity-depth relationship is shown for reference. Velocities to a depth of 140 meters fall slightly below the relationship observed for compacted clays. This difference in velocities may be the result of mineralogical or textural differences, but the exact reason is unknown.

Below 140 meters, the velocities of carbonates are slightly greater than those of clays suggesting that this velocity increase may be attributable to cementation,

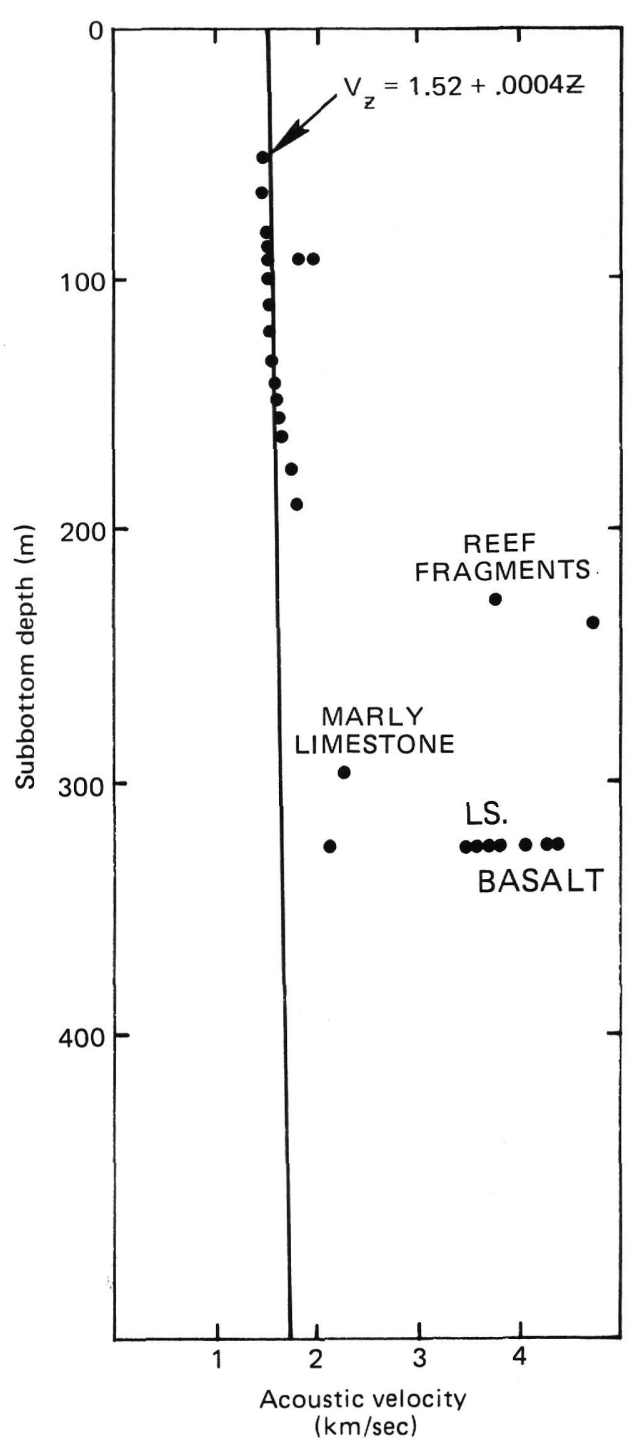

Figure 5. Acoustic velocity profile for nannofossil ooze/chalk at Site 384.

although a density increase is noted at the same depth. From a depth of 140 to 200 meters, it is important to note that the rate of increase in acoustic velocity with depth is greater for calcareous ooze-chalk than for compacted clays. This trend would be expected as cementation bonds and densities increase with depth. Unfortunately, acoustic velocity is not as sensitive to density and cementation variations with depth as other properties such as shear wave velocity. For improved sensitivity to property variations, shear wave velocity should be considered for use in DSDP to better define density, disturbance, and cementation changes at a site.

\section{Laboratory Test Results and Analyses}

Three core samples were taken from Site 387 for analysis of laboratory strength, compression, and other physical properties. Test techniques suggested by Lambe (1951) were used for all tests with only minor changes for soft marine clays. The samples vary in 
length from 15 to $25 \mathrm{~cm}$; therefore, the number of laboratory tests is limited. Summarized in Table 1 are basic sample information obtained onboard ship and in the laboratory. All water content and index property data in the table are adjusted for salt content. Samples are designated by core and section number; for example, Section 1-6 refers to Section 6 of Core 1. Each sample comes from the bottom portion of the core.

All samples are clays of high plasticity $(\mathrm{CH})$ according to the Unified Soil Classification System (Terzaghi and Peck, 1967). They contain little or no calcareous material. The bulk unit weights from trimmed laboratory test specimens vary from 1.45 to $1.53 \mathrm{~g} / \mathrm{cc}$ and agree favorably with the shipboard bulk density determinations. Disturbance is a problem with these samples, although it is not apparent from the radiographs which show homogeneous, unlaminated sediments. Visual observations of trimmed specimens suggest that Section 1-5 is highly remolded and Sections 1-6 and $2-5$ are slightly remolded with some hairline cracks observed in Section 2-5. Test results are subject to these limitations, and disturbance effects will be discussed as they apply to measured engineering properties.

\section{Compression Results}

Five laboratory compression tests were performed in standard laborabory oedometers. Test specimens were approximately $2 \mathrm{~cm}$ high and $6 \mathrm{~cm}$ in diameter. Constant pressures were applied to the specimens for one day until the primary compression was complete and subsequent pressures were doubled up to a peak pressure of about $20 \mathrm{~kg} / \mathrm{cm}^{2}$. Displacement versus time was recorded for all pressure increments. Unloading curves were also obtained for unloading periods of about four hours.

Compression curves are presented in Figures 6 through 10 with the void ratio-log effective pressure $(e-$ $\log p$ ) format (Lambe, 1951) as used in geotechnics. Each curve shows the estimated in situ overburden pressure $\left(p_{\mathrm{o}}\right)$ and preconsolidation pressure $\left(p_{\mathrm{c}}\right)$ which is reconstructed by the Casagrande (1936) technique. The slope of the virgin loading curve or compression index $\left(C_{\mathrm{c}}\right)$ and slope of the unloading curve or swell index $\left(C_{s}\right)$ are shown for each curve. All of these data are summarized in Table 2.

The compression curves show a few interesting features regarding the quality of samples and behavior. Section 1-5 exhibits a linear virgin loading curve, and there is no definitive break in the curve to indicate the precompression pressure. This behavior is typical of thoroughly remolded specimens (Schmertman, 1955). Remolding tends to obliterate stress history and aging effects and provides slightly lower compression indexes than those for an undisturbed specimen. Lambe (1951) suggests that remolding also reduces the coefficient of consolidation. Both coefficients of consolidation and compression indexes are slightly lower for Section 1-5 than for Section 1-6. These samples are from the same lithologic unit and suggest a greater degree of disturbance for Section 1-5.

Sections 1-6 and 2-5 exhibit some disturbance based upon the well-rounded shape of the compression curves; however, disturbance is not as extreme as that

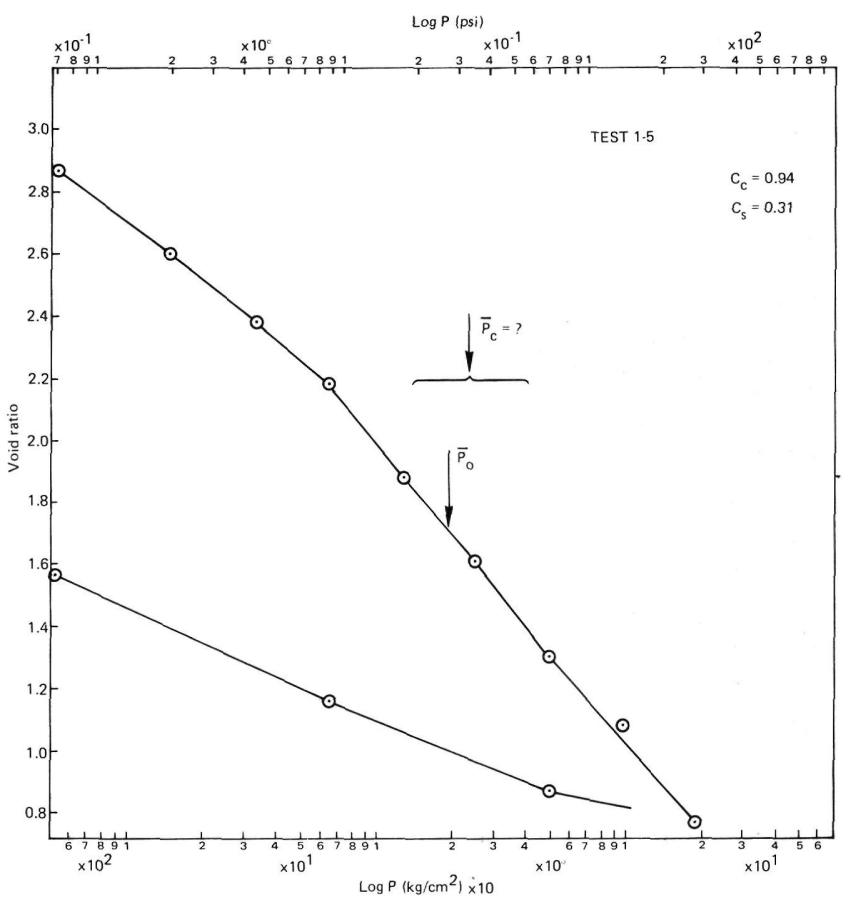

Figure 6. Compression curve for Section 1-5.

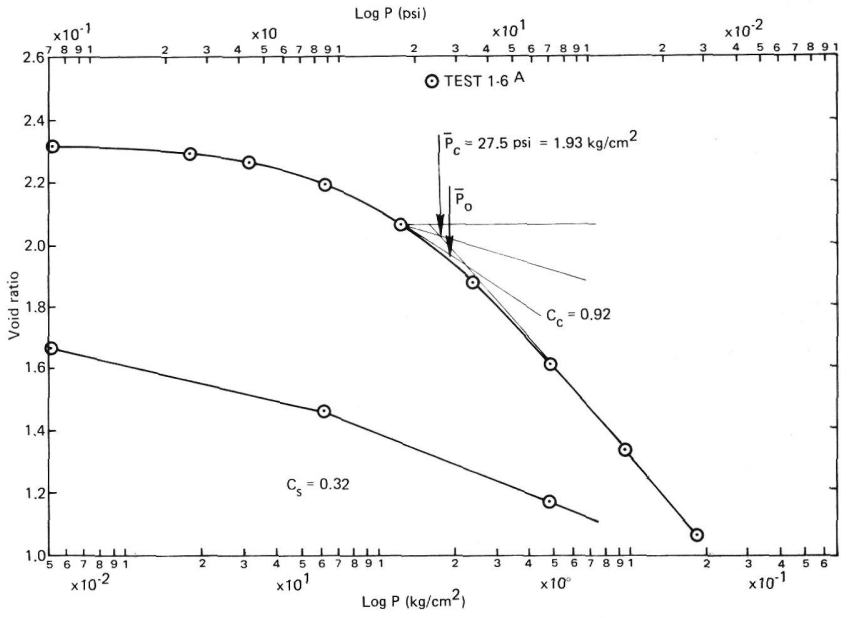

Figure 7. Compression curve for Section 1-6A.

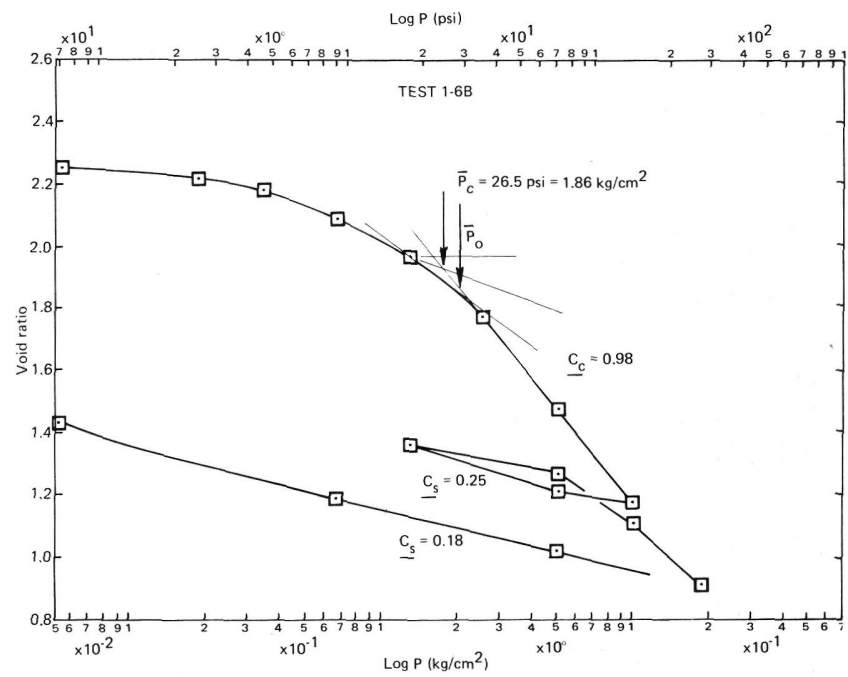

Figure 8. Compression curve for Section 1-6B. 


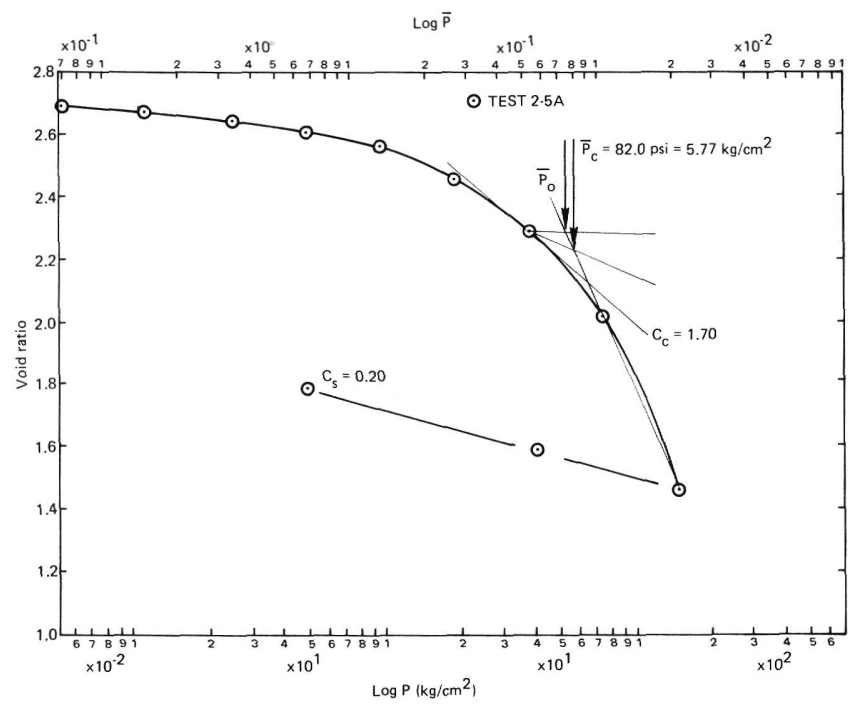

Figure 9. Compression curve for Section 2-5A.

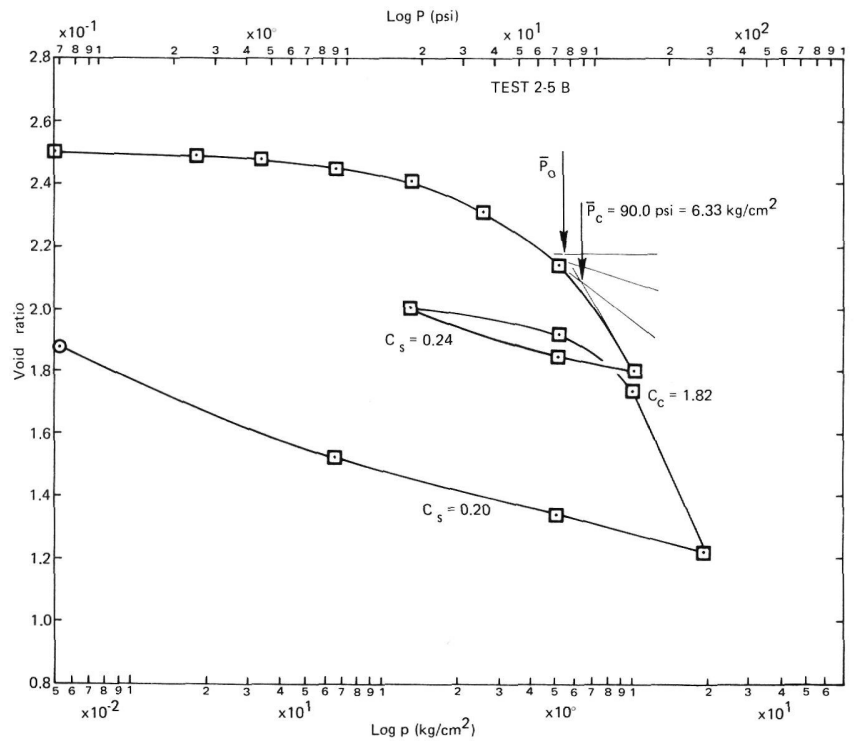

Figure 10. Compression curves for Section 2-5B.

for Section 1-5. Reproducibility may be checked since two compression tests were performed on adjacent segments for these samples. In general, curves 1-6 A and B and curves 2-5 A and B are similar when superimposed with only small differences in the compression parameters. This suggests that the test techniques and sample qualities were similar for each pair of samples. It does not imply that the samples were undisturbed.

For perfect sampling, the in situ effective stress can be assumed to remain approximately constant, and no significant volume changes will occur. However, most DSDP core samples contained water voids or drilling mud between the sediment sample and plastic liner and are not perfect samples. Therefore, it is reasonable to assume these samples will expand when the in situ effective stress is removed during coring. The sample will expand in a drained mode with an uptake of water similar to that experienced in laboratory compression tests during the unloading stage. The data in Figures 7,
8 , and 10 show that for an effective pressure drop from 20 to $0 \mathrm{~kg} / \mathrm{cm}^{2}$ (equivalent to removal from about 300 to $400 \mathrm{~m}$ sub-bottom) the accompanying volume increase is about 30 per cent. This volume increase will result in lower shipboard measurements of bulk density and shear strength and higher values of water content and porosity. As a result, shipboard physical property results should be interpreted with caution. Anticipated volume changes from effective stress removal should be zero at the sea floor where effective stress is zero and increase with effective stress buildup at subbottom depths as estimated above. Volume expansion from stress removal can only occur when excess water is available from coring.

It has been shown that deep-sea sediments often behave like over-consolidated soil. This behavior is not for the usual reasons of desiccation or erosional unloading (Bryant et al., 1974), but is often explained by interparticle cementation. Also, it has been suggested that aging of slowly deposited marine clays (Noorany and Gizinski, 1970; Demars, 1975) may account for this overconsolidated behavior as explained by Bjerrum (1973). Overconsolidation is generally inferred from the ratio of preconsolidation pressure from oedometer tests to the overburden pressure (estimated from sample depth and bulk density). A ratio greater than one suggests an overconsolidated soil, and less than one an underconsolidated soil. As observed in Figures 7 through 10, the ratios for all specimens are approximately one, which is typical of normally loaded clays. Unfortunately, coring disturbance and temperature change probably influence the value of laboratory preconsolidation pressures, and these effects are unknown. Based on Bjerrum's work, deep water marine sediments should be aged and exhibit overconsolidated behavior. More work is therefore needed on the compression and strength behavior of slowly deposited and apparently aged clays. Further studies will require better quality samples and in situ measurement of engineering properties.

Empirical correlations have proven useful for preliminary estimates of engineering properties. Several correlations exist for estimates of compression index from index properties such as liquid limit for land clays (Terzaghi and Peck, 1967) and marine clays (Herrmann et al., 1972) and plasticity index for marine calcareous clays (Demars, 1975). These relationships are shown in Figure 11 with the data from this study. It should be noted that remolding tends to reduce compression indexes, and this may have a slight influence on the test data. In general, there is very good agreement between these data and the relationship proposed by Herrmann et al. (1972) and Demars (1975) for marine clays. The tendency has been for marine clays to be more compressible than land clays, which is apparently related to their different sedimentary environments.

\section{Shear Strength}

A double-stage triaxial compression test $(\overline{C I U})$ was performed on each of the three samples obtained at Site 387 in an effort to obtain the effective strength pa- 

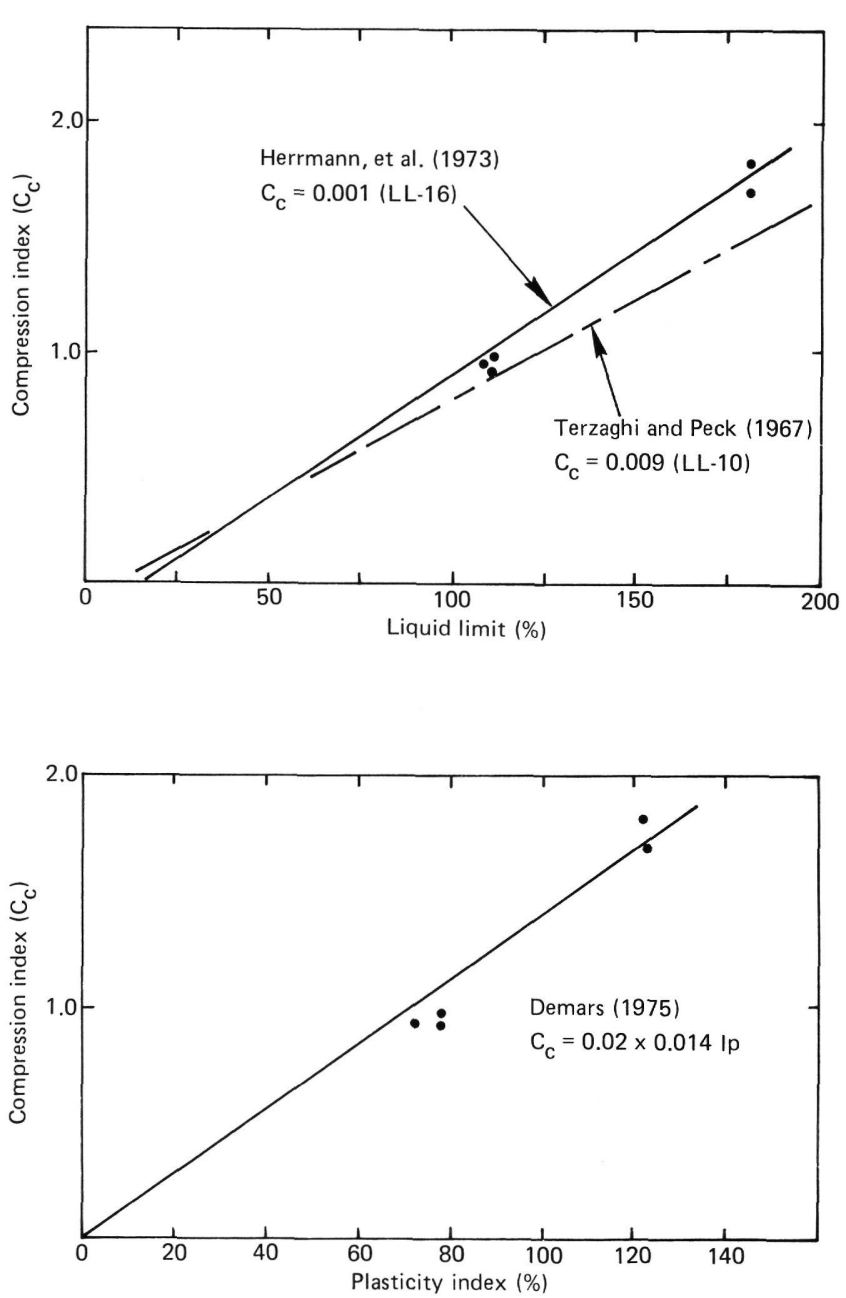

Figure 11. Comparison of compression indexes with established empirical relationships.

rameters. It was desirable to consolidate specimens to stresses that are equal to or greater than the in situ overburden pressures to minimize the effects of disturbance (Ladd and Lambe, 1963) and possible overconsolidation. This procedure was used for Sections 1-5 and 1-6; but because of equipment pressure limitations, this procedure was not possible for the first-stage test of Section 2-5.

All samples were consolidated isotropically for about one day with the aid of radial filter drains. Subsequently, the samples were back pressured overnight at $1 \mathrm{~kg} / \mathrm{cm}^{2}$ to insure saturation. The specimens were then sheared with measurements of deviator stress, confining stress, axial displacement, and pore water pressure. Following the first stage of testing, this procedure was repeated for a second stage at a higher consolidation pressure. All specimens were sheared at a rate of about 1 per cent per hour with each stage strained to about 5 to 6 per cent.

From the recorded data, axial strains and major and minor effective principal stresses $\left(\bar{\sigma}_{1}\right.$ and $\left.\bar{\sigma}_{3}\right)$ were determined. Using the effective principal stresses, the parameters

$$
q=\frac{\bar{\sigma}_{1}-\bar{\sigma}_{3}}{2} \text { and } \bar{p}=\frac{\bar{\sigma}_{1}+\bar{\sigma}_{3}}{2}
$$

were determined for each level of axial strain. Thus, stress paths were plotted (Figure 12) so that the MohrCoulomb failure envelope and effective strength parameters could be determined (Lambe and Whitman, 1969). In addition, the pore pressure parameters $A$ and $B$ were obtained, and they are summarized in Table 3 with other strength information. The subscript $f$ in Table 3 denotes failure which was defined as the peak deviator stress.

From prior work (Demars, 1975), a back pressure of 1 to $2 \mathrm{~kg} / \mathrm{cm}^{2}$ was considered adequate for insuring saturation of marine clays from sub-bottom depths of 8 meters or less. Generally, pore water $B$ parameters of 0.95 or better and preferably 1.0 are desired to insure reliable pore water pressure measurements. As summarized in Table 3 , less than desirable $B$ parameters were obtained for Sections 1-5 and 2-5. These low $B$ parameters suggest that excess pore pressures and effective stresses are not accurately known and lend some confusion to interpretation of results. Nevertheless, the effective friction angles and $A$ parameters at failure for
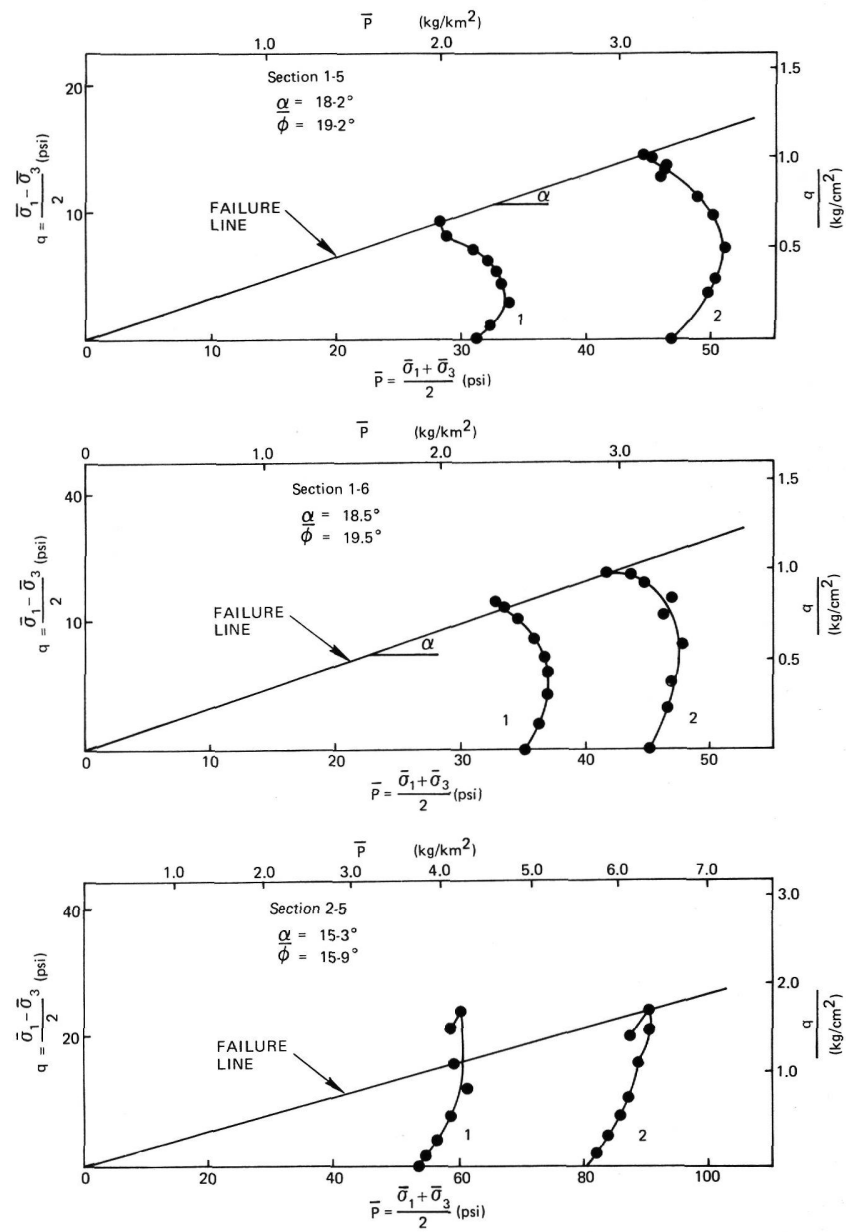

Figure 12. Stress paths for double-stage triaxial compression tests. 
TABLE 2

Consolidation Test Data

\begin{tabular}{|c|c|c|c|c|c|c|c|}
\hline Sample & $\begin{array}{c}\text { Adjusted }^{\mathrm{a}} \\
\text { Water } \\
\text { Content }\end{array}$ & $\begin{array}{l}\text { Void } \\
\text { Ratio }\end{array}$ & $\begin{array}{l}\text { Comp. } \\
\text { Index } \\
\mathrm{C}_{\mathrm{c}}\end{array}$ & $\begin{array}{c}\text { Swell } \\
\text { Index } \\
\mathrm{C}_{\mathrm{S}}\end{array}$ & $\begin{array}{c}\text { Precon. } \\
\text { Pres. } \\
\mathrm{p}_{\mathrm{c}}{ }^{2} \\
\left(\mathrm{~kg} / \mathrm{cm}^{2}\right)\end{array}$ & $\begin{array}{c}\text { Overburd. }^{\mathrm{c}} \\
\text { Pres. } \\
\mathrm{p}_{\mathrm{o}} \\
\left(\mathrm{kg} / \mathrm{cm}^{2}\right)\end{array}$ & $\begin{array}{l}\text { Coef. of } \\
\text { Consol. } \\
\mathrm{C}_{\mathrm{v}} \times 10^{-4} \\
\left(\mathrm{~cm}^{2} / \mathrm{sec}\right)\end{array}$ \\
\hline $1-5 \mathrm{~A}$ & 105.2 & 2.86 & 0.94 & 0.31 & - & 1.95 & 0.0006 \\
\hline $1-6 \mathrm{~A}$ & 85.0 & 2.32 & 0.92 & 0.32 & 1.93 & 2.02 & 0.0014 \\
\hline $1-6 \mathrm{~B}$ & 83.3 & 2.26 & 0.98 & 0.25 & 1.86 & 2.02 & 0.0012 \\
\hline $2-5 \mathrm{~A}$ & 99.8 & 2.70 & 1.70 & 0.20 & 5.77 & 5.29 & 0.0012 \\
\hline $2-5 B$ & 92.9 & 2.51 & 1.82 & 0.24 & 6.33 & 5.29 & 0.0010 \\
\hline
\end{tabular}

aWater content adjusted for salt.

bVoid ratio computed for saturated soil with specific gravity of solids, $G_{S}=2.72$ (assumed).

cOverburden pressure computed from Table 1 data with buoyant unit weight of $0.50 \mathrm{~g} / \mathrm{cc}$.

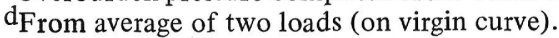

TABLE 3

Double-Stage Triaxial Compression Results

\begin{tabular}{|c|c|c|c|c|c|c|c|c|}
\hline \multirow[b]{2}{*}{ Section } & \multirow[b]{2}{*}{ Stage } & \multirow{2}{*}{$\begin{array}{c}\text { Consol. }^{\mathrm{a}} \\
\text { Press. }^{2} \\
\bar{\sigma}_{\mathrm{c}}\left(\mathrm{kg} / \mathrm{cm}^{2}\right) \\
\end{array}$} & \multirow{2}{*}{$\begin{array}{c}q_{f}= \\
\sigma_{1}-\sigma_{3} \\
2 \\
\left(\mathrm{~kg} / \mathrm{cm}^{2}\right)\end{array}$} & \multirow{2}{*}{$\begin{array}{c}p_{f}= \\
\bar{\sigma}_{1}+\bar{\sigma}_{3} \\
2\end{array}$} & \multicolumn{2}{|c|}{$\begin{array}{l}\text { Pore water } \\
\text { Parameters }\end{array}$} & \multirow{2}{*}{$\begin{array}{c}\text { Effective } \\
\text { Friction } \\
\text { Angle } \\
\bar{\phi} \mathrm{d}\end{array}$} & \multirow{2}{*}{$\begin{array}{l}\text { Ratio } \\
q_{f} / \bar{\sigma}_{c}\end{array}$} \\
\hline & & & & & $B^{\mathrm{b}}$ & $A_{f}{ }^{\mathrm{c}}$ & & \\
\hline \multirow{2}{*}{$1-5$} & 1 & 2.22 & 0.64 & 1.99 & 0.75 & 0.68 & 19.2 & \multirow{3}{*}{0.31} \\
\hline & 2 & 3.30 & 1.03 & 3.13 & 0.87 & 0.58 & & \\
\hline \multirow{2}{*}{$1-6$} & 1 & 2.47 & 0.82 & 2.30 & 0.99 & 0.60 & 19.5 & \\
\hline & 2 & 3.16 & 0.98 & 2.92 & 0.00 & 0.58 & \multirow{3}{*}{15.9} & 0.31 \\
\hline \multirow{2}{*}{$2-5$} & 1 & 3.76 & 1.61 & 4.22 & 0.41 & 0.35 & & \\
\hline & 2 & 5.64 & 1.73 & 6.34 & 0.99 & 0.33 & & 0.31 \\
\hline
\end{tabular}

ä̈stimated overburden pressures are listed in Table 2.

$\mathrm{b}_{B}=\Delta u / \Delta \sigma_{C}$

$\mathrm{c}_{A_{f}}=\Delta u / \Delta \sigma_{1}$ for undrained triaxial test.

$\mathrm{d}$ The effective friction angle was determined for normally consolidated samples with the assumption that effective cohesion, $\mathrm{c}=0$.

Sections 1-5 and 1-6 are similar or reproducible, even though different degrees of sample saturation were attained. For both samples, the values of $A_{\mathrm{f}}$ and $\bar{\phi}$ fall within the expected range for normally consolidated plastic clays. The $A$ parameters are on the low side of expected values probably because of sample disturbance.

For Section 2-5, the effective friction angle is somewhat lower than that for Sections 1-5 and 1-6, and this trend would be expected because of the greater plasticity of Section 2-5 (Kenney, 1959). The $A$ parameter at failure of Section 2-5 is typical for a slightly overconsolidated clay; however, the credibility of this measurement is lacking because of sample disturbance and the low degree of saturation as indicated by the $B$ parameters. Consolidation test results suggest that stage 2 of Section 2-5 should behave in a fashion similar to a normally consolidated sample, but it actually behaves like a slightly overconsolidated clay.

The ratio of strength $\left(q_{\mathrm{f}}\right)$ to consolidation pressure $\left(\sigma_{\mathrm{c}}\right)$ can be determined from triaxial compression tests. This ratio is similar to the $c / \bar{p}$ ratio presented in Figure 3. As shown in Table 3, the ratio

$$
q_{\mathrm{f}} / \bar{\sigma}_{\mathrm{c}}=0.31
$$

exist for all three specimens. This compares with values of $c / \bar{p}$ less than 0.20 for shipboard vane shear strength values, but is within the expected range of 0.3 to 0.4 . It is somewhat less than the ratios estimated by Skempton's relationship

$$
c / \bar{p}=0.11+0.0037(P I)
$$

These strength values determined in the laboratory are considered to be a better, though possibly higher (Ladd and Lambe, 1963), estimate of in situ strengths than is obtained onboard ship since disturbance effects can be reduced with laboratory testing if the effective stresses are known.

\section{CONCLUSIONS}

1. The most significant factors influencing engineering and physical property data are consolidation from overburden, sample disturbance from coring, and particle cementation. Disturbance may include remolding of cohesive sediments or remolding plus water content change for granular sediments. Cementation results from silica, carbonate, and organic material.

2. Volume increases of 30 per cent or more are possible for compacted clays removed from 300 to 400 
meters sub-bottom. Excess water is available from drilling mud or free fluid between sample and liner. This water contributes to volume increases from (a) drained unloading of samples in liner, (b) temperature expansion, and (c) thermal flow. Physical properties are determined for these expanded samples.

3. The unadjusted velocity gradient for compacted clays is $0.4 \mathrm{sec}^{-1}$. This gradient is slightly lower than expected field velocity gradients partly because of volume expansion of test specimens and sample disturbance.

4. The velocity gradient for nannofossil ooze/chalk appears to increase with subbottom depth. This change is attributed to increasing cementation bonds with burial as ooze converts to chalk.

5. Compression tests reveal the samples to be normally consolidated and not aged or overconsolidated as expected. However, volume expansion and sample disturbance possibly destroy aging and secondary compression effects.

6. Compression indexes for deep marine clays compare favorably with established empirical relationships involving liquid limit or plasticity index for shallow marine clays.

7. The ratio of strength to effective pressure $(c / \bar{p})$ was 0.31 for the three normally consolidated triaxial compression specimens. This $c / \bar{p}$ ) ratio is substantially higher than that determined from shipboard vane shear strengths, and it is typical of normally consolidated clays.

8. Effective friction angles vary from 16 to 20 degrees, and $A$ parameters at failure are about 0.6 . These values are typical of normally consolidated plastic clays.

\section{RECOMMENDATIONS}

1. Physical properties such as strength and acoustic velocity are dependent upon the effective state of stress. In situ duplication of effective stress can best be achieved in the laboratory, whereas disturbance as experienced on ship severely influences effective stress state. A more vigorous laboratory test program is needed for representative in situ physical properties.

2. Corrections should be made to shipboard physical properties such as bulk density, porosity, and water content that are influenced by temperature expansion and drained unloading. It is reasonable at this time to suggest that part of the thermal effect may be accounted for by a correction in water content. It may be possible to develop tables or graphs for rapid corrections, but more research is needed on this problem before a program is instituted.

3. In situ measurement of strength with a penetrometer or water content with a nuclear probe would provide reliable data and help calibrate shipboard and laboratory measurement of these quantities. The electronics for such a program are available onboard ship, and only the wireline tools need to be developed.

4. A shear wave velocimeter should be developed for shipboard use to study disturbance and cementation with subbottom depth. Shear wave velocity is more sensitive to disturbance and cementation variations than compressional velocity.

\section{ACKNOWLEDGMENTS}

This study was made possible with financial support of the National Science Foundation.

Thanks are due to Ms. A. Gilbert and T. Wood and Mssrs. R. Myers, T. Gustafson, B. Hamlin, and D. Cameron of the DSDP for assistance with shipboard physical property determinations. Mr. H. Lee of the U.S. Naval Civil Engineering Laboratory and Mr. J. Prizio of the U.S. Geological Survey, Conservation Division, reviewed the manuscript, and their efforts are appreciated. Laboratory tests were performed at the University of Rhode Island.

\section{REFERENCES}

Bennett, R. H. and Keller, G. H., 1973. Physical properties evaluation. In van Andel, T. H., Heath, G. R., et al., Initial Reports of the Deep Sea Drilling Project, v. 16: Washington (U. S. Government Printing Office), p. 521-528.

Bjerrum, L. 1973. Problems of soil mechanics and construction on soft clays: State-of-the-Art Report to the Session IV, Eighth International Conference on Soil Mechanics and Foundation Engineering, Moscow.

Boyce, R. E., 1974, DSDP procedures using the Gamma Ray Attenuation Porosity Evaluation (GRAPE). Instructions for grain density, wet-bulk density, water content, and porosity determinations by individual samples and Gamma Ray Attenuation Porosity Evaluator. A DSDP instruction handbook: La Jolla (Scripps Institution of Oceanography).

Bryant, W. R., Deflache, A. P., and Trabant, P. K., 1974 Consolidation of Marine clays and carbonates. Deep sea sediments: physical and Mechanical properties: In Inderbitzen, A. L. (Ed.), New York (Plenum Press).

Demars, K. R., 1975. Strength and stress-strain behavior of deep ocean carbonate soils: Ph.D. Dissertation, University of Rhode Island.

Hamilton, E. L., 1974. Prediction of deep sea sediment properties, In Inderbitzen, A. L., (Ed.), Deep sea sediments: physical and mechanical properties: New York, (Plenum Press), p. 1-43.

Herrmann, H. G., Rocker, K., Jr., and Babineau, P. H., 1972. Lobster and FMS: devices for monitoring long-term seafloor foundation behavior, Tech. Rept. R-775, Naval Civil Engineering Laboratory, Port Hueneme, California.

Hvorslev, M. J., 1949. Subsurface exploration and sampling of soils for civil engineering purposes: Vicksburg, Mississippi: Waterways Experiment Station.

Kenney, T. C., 1959. Discussion: Am. Soc. Civ. Eng. Proc., v. 85 , pp. 67-79.

Kenney, T. C., 1967. Field measurements of in-situ stresses in quick clays: Geotechnical Conf. Proc., Oslo, p. 49-55.

Ladd, C. C. and Lambe, T. W., 1963. The strength of undisturbed clays determined from undrained tests: $A S T M$ Standard Tech. Publ., no. 361, p. 342-371.

Lambe, T. W., 1951. Soil testing for engineers. New York (John Wiley and Sons).

Lambe, T. W. and Whitman, R. V., 1969. Soil mechanics: New York (John Wiley and Sons).

Laughton, A. S., 1957. Sound propagation in compacted ocean sediments, Geophysics, v. 22, p. 233-260. 
Lee, J. J., 1973. Measurements and estimates of engineering and other physical properties, In Creager, J. S., Scholl, D. W., et al., Initial Reports of the Deep Sea Drilling Project, v. 19: Washington (U. S. Government Printing Office), p. 701-720.

Mitchell, J. K., 1976. Fundamentals of soil behavior: New York (John Wiley and Sons).

Noorany, I. and Gizinski, S. F., 1970. Engineering properties of submarine soils: State-of-the-Art Review: Am. Soc. Civ. Eng. Proc. Soil Mechanics and Foundation Division, v. 96, p. $1735-1762$.

Rocker, K., 1974. Physical properties measurements and test procedures for Leg 27. In Veevers, J. J., Heirtzler, J. R., et al., Initial Reports of the Deep Sea Drilling Project, v. 27: Washington (U. S. Government Printing Office), p. 433-444.

Schlanger, S. O., Douglas, R. G., Lancelot, Y., Moore, T. C. and Roth, P. H., (1973). Fossil preservation and diagene- sis of pelagic carbonates from the Magellan Rise, Central North Pacific Ocean. In Winterer, E. L., Ewing, J. I., et al., Initial Reports of the Deep Sea Drilling Project, v. 17: Washington (U. S. Government Printing Office), p. 407-427.

Schmertman, J. M., 1955. The undisturbed consolidation of clay: Am. Soc. Civ. Eng. Trans., v. 120.

Sherif, M. A. and Burrows, C. M., 1969. Temperature effects on the unconfined shear strength of saturated cohesive soil, Highway Res. Bull., Spec. Rept. 103, p. 267-272.

Skempton, A. W., 1954. Discussion of the structure of inorganic soil: J. Soil Mechanics Found. Div., ASCE, v. 80.

Terzaghi, K. and Peck, R. B., 1967. Soil mechanics in engineering practice, 2nd Ed: New York (John Wiley and Sons, Inc.).

Yong, R. N. and Warkentin, B.P., 1966. Introduction to soil behavior: New York (Macmillan Co.). 